\title{
KESALAHAN SISWA SMP DALAM MENYELESAIKAN SOAL CERITA PADA MATERI ARITMATIKA SOSIAL
}

\author{
Nita Yunia1, Luvy Sylviana Zanthy² \\ 1,2 IKIP Siliwangi, Jl. Terusan Jenderal Sudirman, Cimahi, Indonesia \\ Email: nitayunia8@gmail.com
}

\begin{abstract}
This research aims to analyse and describe the mistakes of students in solving social arithmetic stories. This type of research is a qualitative descriptive. The subject of this study was four students of grade VIII in Bina Putra Indonesia Junior High. Data collection is done by written tests and live interviews with students. The results showed that the students' mistakes in resolving the story of social arithmetic material varied, including errors in transforming the story into mathematical models, errors using social arithmetic formulas and errors students in concluding the answers done.
\end{abstract}

Keywords: Data analysis, story problems, social arithmetic

\section{ABSTRAK}

Penelitian ini bertujuan untuk menganalisis dan mendeskripsikan kesalahan siswa dalam menyelesaikan soal cerita aritmatika sosial. Jenis penelitian ini adalah deskriptif kualitatif. Subjek penelitian ini adalah empat siswa kelas VIII di SMP Bina Putra Indonesia. Pengumpulan data dilakukan dengan tes tertulis dan wawancara langsung dengan siswa. Hasil penelitian menunjukkan bahwa kesalahan siswa dalam menyelesaikan soal cerita pada materi aritmatika sosial bervariasi, diantaranya kesalahan mengubah soal cerita ke dalam model matematika, kesalahan menggunakan rumus aritmatika sosial dan kesalahan siswa dalam menyimpulkan jawaban yang dikerjakan.

Kata kunci: Analisis data, soal cerita, aritmatika sosial

Dikirim: 08 Januari 2020; diterima: 15 Februari 2020; dipublikasikan: 30 Maret 2020

Cara sitasi: Yunia, N., \& Zanthy, L. S. (2020). Kesalahan siswa smp dalam menyelesaikan soal cerita pada materi aritmatika sosial. Teorema: Teori dan Riset Matematika, 5(1), 105-116. 


\section{PENDAHULUAN}

Pendidikan menurut Undang-Undang Republik Indonesia Nomor 20 Tahun 2003 tentang Sistem Pendidikan Nasional (Sisdiknas) Bab 1 Pasal 1 yaitu: "Pendidikan adalah usaha sadar dan terencana untuk mewujudkan suasana belajar dan proses pembelajaran agar peserta didik secara aktif mengembangkan potensi dirinya untuk memiliki kekuatan spiritual keagamaan, pengendalian diri, kepribadian, kecerdasan, akhlak mulia, serta keterampilan yang diperlukan dirinya, masyarakat, bangsa dan Negara. "Peran pendidikan sangat penting untuk menciptakan kehidupan yang cerdas, damai, terbuka, dan demokratis (Wahyuni, 2018). Salah satu cara untuk meningkatkan sumber daya manusia (SDM) saat ini adalah dengan meningkatkan kualitas pembelajaran dan proses pembelajaran yang bermutu (Permatasari, 2014).

Menurut Peraturan Menteri Pendidikan Nasional atau Permendiknas Nomor 22 Tahun 2006 tentang standar isi mata pelajaran matematika untuk semua jenjang pendidikan dasar dan menengah dinyatakan bahwa tujuan mata pelajaran matematika dipelajari di sekolah adalah agar siswa mampu: (1) memahami konsep matematika, menjelaskan keterkaitan antar konsep dan mampu mengaplikasikan konsep/algoritma secara luwes, akurat, efisien dan tepat dalam pemecahan masalah; (2) menggunakan penalaran pada pola dan sifat, memanipulasi matematika dalam membuat generalisasi, penyusunan bukti, atau melakukan penjelasan gagasan dan pernyataan matematika; (3) memecahkan masalah yang meliputi kemampuan memahami masalah, merancang model matematika, menyelesaikan model dan menafsirkan solusi yang diperoleh; (4) mengkomunikasikan gagasan dengan simbol, diagram, atau media lain untuk memperjelas keadaan atau masalah; dan (5) memiliki sikap menghargai kegunaan matematika dalam kehidupan. Berdasarkan standar isi yang dipaparkan tersebut, diperlukan adanya suatu inovasi pembelajaran yang berupaya mampu mengoptimalkan pembelajaran bermakna, menyenangkan, serta mampu mendorong untuk mengkonstruk dan mengembangkan pengetahuan yang telah dimiliki oleh siswa sebelumnya (Zakiah et.al, 2019).

Matematika merupakan ilmu hitung yang sangat penting untuk diterapkan di lingkungan sekolah maupun lingkungan sekitar, karena berbagai segi kehidupan yang kita alami saat ini banyak interaksi yang menggunakan matematika di dalam kehidupan. Hal ini sesuai dengan yang diungkapkan Simarmata,et.al (2018) bahwa dalam segi kehidupan banyak mata pelajaran yang memerlukan keterampilan matematika. Zanthy (2016) mengungkapkan bahwa banyak masalah dalam kehidupan yang dapat diselesaikan dengan menggunakan model matematika. Oleh sebab itu, matematika sangat penting untuk dipelajari. Menurut BSNP matematika merupakan pengetahuan universal yang mendasari perkembangan teknologi modern yang mempunyai peran penting dalam mengembangkan daya pikir manusia, serta sebagai sarana komunikasi sains tentang pola-pola untuk melatih berpikir logis, kritis, kreatif, dan inovatif (Halim \& Rasidah, 2019).

Matematika sebagai suatu bahasa tentunya sangat diperlukan sebagai alat komunikasi baik secara lisan maupun tulisan sehingga informasi yang disampaikan dapat diketahui dan dipahami oleh orang lain. Seperti apa yang dikemukakan Cockroft (Aminah et.al, 2018) bahwa "We believe that all these percepcions of the usefulness of mathematics arise from the fact that mathematics provides a means of communication which is powerful, concise, and unambiguous". Pernyataan ini menunjukkan tentang perlunya para siswa belajar matematika dengan alasan bahwa matematika merupakan alat komunikasi yang sangat kuat, teliti, dan tidak membingungkan. Proses pembelajaran ditandai dengan adanya perubahan perilaku pada diri siswa. Keberhasilan dalam pelajaran matematika dapat dipengaruhi oleh beberapa faktor, yaitu faktor dari dalam (internal) maupun faktor dari luar (eksternal) diri siswa tersebut (Wahyudin, 2016).

Menurut Setiani et.al (2018) aritmatika sosial merupakan salah satu materi matematika yang dipelajari di SMP kelas VII. Banyak hal yang dipelajari di dalam materi tersebut, salah satunya interaksi yang dilakukan ketika terjadinya jual beli antar masyarakat yang menggunakan mata uang. Dalam kurikulum Kemendikbud beberapa diantara subpokok bahasan dalam aritmatika sosial yaitu diskon, pajak, bruto, tara dan neto serta bunga tunggal (Henidarwati et.al, 2016). Menurut Inayah (2018) aritmatika sosial merupakan materi pembelajaran yang berkaitan langsung dengan kehidupan sehari- 
hari, banyak materi aritmatika sosial yang tanpa kita sadari didapatkan dari permasalahan di kehidupan sekitar. Pada materi aritmatika sosial cenderung soal yang diberikan merupakan soal cerita. Hal ini sesuai dengan yang diungkapkan Paramitha (2017) bahwa materi aritmatika sosial cenderung melibatkan soal cerita dalam setiap pembahasannya. Isna \& Kurniasari (2018) menyatakan bahwa materi aritmatika sosial digunakan dalam mengidentifikasi tingkat berpikir kreatif siswa karena materi ini memungkinkan siswa menyelesaikan permasalahan matematika menggunakan berbagai cara penyelesaian. Menurut Silver bahwa pembelajaran yang mengkoneksikan antara materi pelajaran dengan konteks kehidupan sehari-hari dapat memberikan siswa banyak pengalaman dalam menafsirkan masalah dan mungkin pula menumbuhkan ide-ide yang bervariasi dalam menyelesaikan permasalahan (Zakiah et.al, 2019).

Menurut Fatimah \& Zakiah (2018) bahwa masalah yang relevan untuk meningkatkan kemampuan berpikir matematis siswa adalah berupa masalah-masalah kontekstual nonrutin (contextual problems). Pemberian masalah kontekstual nonrutin dapat berupa soal cerita. Menurut Budiyono (Halim \& Rasidah, 2019) bahwa soal cerita merupakan salah satu bentuk soal yang menyajikan permasalahan dalam kehidupan sehari-hari dalam bentuk narasi atau cerita. Soal cerita biasanya diwujudkan dalam kalimat yang didalamnya terdapat persoalan atau permasalahan yang penyelesaiannya menggunakan keterampilan berhitung. Kesulitan yang dialami siswa dalam menyelesaikan soal akan diakibatkan karena siswa kurang cermat dan kesulitan memahami cerita sehingga siswa sulit dalam membuat model matematika dan menemukan konsep yang tepat (Mulyani \& Hanifah, 2018)

Kamus Bahasa Indonesia (2008:60) menyatakan bahwa analisis adalah penyelidikan suatu peristiwa (karangan, perbuatan dan sebagainya) untuk mengetahui apa sebab-sebabnya, bagaimana duduk perkaranya, dan sebagainya. Sedangkan kesalahan dalam Kamus Bahasa Indonesia (2008: 1247), adalah kekeliruan, perbuatan yang salah (melanggar hukum dan sebagainya). Jadi analisis kesalahan adalah sebuah upaya penyelidikan terhadap suatu peristiwa penyimpangan untuk mencari tahu apa yang menyebabkan suatu peristiwa penyimpangan itu bisa terjadi.

Menurut Polya bahwa kemampuan menyelesaikan soal merupakan kemampuan yang dimiliki siswa untuk menyelesaikan soal-soal matematika yang meliputi: (1) kemampuan menuliskan aspek yang diketahui; (2) kemampuan menuliskan aspek yang ditanyakan; (3) kemampuan membuat model matematika; (4) kemampuan menyelesaikan model matematika; dan (5) kemampuan menjawab pertanyaan soal (Wahyudin, 2016). Adapun faktor-faktor yang melatarbelakangi siswa melakukan kesalahan menurut Hamalik (Astutik \& Kurniawan, 2015) adalah faktor yang dapat menimbulkan kesulitan belajar siswa. Faktor munculnya kesulitan siswa menjawab soal digolongkan menjadi dua yaitu: (1) faktor yang berasal dari diri siswa sendiri (faktor internal); (2) faktor yang berasal dari luar (faktor eksternal). Faktor-faktor yang menyebabkan siswa melakukan kesalahan melalui faktor internal diantaranya: (1) kurangnya pemahaman siswa pada materi; (2) kesulitan siswa dalam memahami soal; (3) tidak teliti dalam menjawab soal contohnya siswa tidak menuliskan apa yang diketahui dan ditanyakan dari soal tersebut, ketergesa-gesaan siswa seringkali tidak menyimpukan hasil jawaban; (4) kebiasaan belajar siswa; (5) kondisi siswa, seperti sakit dan tidak percaya diri menjawab soal.

Penyebab kesalahan-kesalahan yang dilakukan siswa dalam mengerjakan soal cerita matematika dikarenakan siswa kurang menguasai bahasa, contohnya siswa tidak paham dengan pertanyaan, tidak memahami arti kata, tidak memahami konsep, dan kurang memahami teknik berhitung (Susilowati, L \& Ratu, 2018).

Kesalahan siswa dalam menyelesaikan soal cerita menjadi salah satu petunjuk untuk mengetahui sejauh mana siswa mengetahui konsep dasar matematika. Adapun Rofi'ah et.al, (2019) menyatakan ada beberapa karakteristik kesulitan belajar matematika diantaranya kurangnya kemampuan matematika dini, kesulitan pada bahasa dan membaca, kesulitan pada konsep arah dan waktu, serta kesulitan matematika lain. Menurut Runtukahu \& Kandou siswa yang mengalami kesulitan belajar matematika sering melakukan kesalahan atau kekeliruan dalam belajar berhitung, maupun menyelesaikan soal cerita (Andayani \& Lathifah, 2019). 
Siswa dikatakan mengalami kesalahan konsep jika siswa tidak mampu memahami simbol dan nilai tempat, kekeliruan dalam perhitungan, kekeliruan dalam penggunaan proses, tulisan yang tidak dapat dibaca, dan kesalahan menginterpretasikan jawaban kalimat matematika. Indikator lemahnya pemahaman konsep dasar siswa antara lain dikarenakan kesalahan dalam memahami pertanyaan soal sehingga dalam proses pengerjaannya salah, kesalahan dalam mengerjakan soal karena siswa lupa dalam proses pengerjaan, dan tidak teliti dalam mengerjakan soal (Rismawati \& Asnayani, 2019). Analisis kesalahan yang dilakukan oleh siswa menurut Kastolan (Lutfia \& Zanthy, 2018) dapat dibedakan menjadi 3 jenis, yaitu kesalahan konseptual, kesalahan prosedural, dan kesalahan teknik. Adanya analisis kesalahan dapat mempermudah mengklasifikasi kesalahan yang dilakukan siswa dalam menyelesaian soal aritmatika sosial.

Kesalahan siswa dalam mengerjakan soal cerita perlu dianalisis sehingga diketahui proses berpikir siswa dalam memahami soal yang diberikan, setiap langkah-langkah jawaban siswa perlu diamati karena dari jawaban tersebut kita dapat mengetahui jawaban siswa sesuai dengan prosedur yang ditentukan atau tidak. Sering kali siswa SMP kelas VIII dalam mengerjakan soal aritmatika sosial keliru dalam menjawab soal yang diberikan salah satunya dalam menghitung bunga tunggal dan menghitung pajak. Selain itu, kesalahan siswa dalam menjawab soal bervariasi. Kesalahan dalam menyelesaikan soal cerita terjadi ketika kurangnya pemahaman konsep dalam matematika itu sendiri, mengkoreksi setiap langkah yang dikerjakan siswa merupakan salah satu solusi. Menurut Nurussafa'at et.al (2016) kesalahan menyelesaikan soal cerita yang dilakukan siswa perlu adanya tindakan lebih lanjut, agar mendapatkan gambaran yang rinci atas kelemahan-kelemahan tersebut.

Tujuan penelitian ini yaitu untuk menganalisa dan mendeskripsikan kesalahan siswa dalam mengerjakan soal aritmatika sosial, mengetahui sejauh mana pemahaman siswa serta cara berpikir siswa dalam memecahkan suatu permasalahan yang diberikan. sehingga bagi guru dan siswa dapat dijadikan suatu acuan guna memperbaiki pembelajaran manjadi lebih baik.

\section{METODE PENELITIAN}

Penelitian ini menggunakan jenis penelitian deskriptif dengan pendekatan kualitatif. Penelitian ini dilakukan di SMP Bina Putera Indonesia kelas VIII di Padalarang. Subjek penelitian dipilih dengan menggunakan teknik purposive sampling sebanyak empat orang siswa. Teknik pengumpulan yang dilakukan dengan menggunakan tes dan wawancara langsung. Tes bertujuan untuk mengetahui sejauh mana kesalahan siswa dalam menjawab soal materi aritmatika sosial, sedangkan wawancara dilakukan guna mengetahui penyebab kesalahan siswa. Berdasarkan Newman (Nuryana \& Rosyana, 2019) bahwa jenis-jenis kesalahan siswa dalam menyelesaikan soal, yaitu kesalahan membaca (reading error), kesalahan pemahaman (comprehension error), kesalahan transformasi (transformation error), kesalahan keterampilan proses (process skill error) dan kesalahan penyimpulan (encoding error). Soal tes yang diberikan berjumlah empat buah materi aritmatika sosial. Nilai yang didapatkan dari hasil tes kemudian diurutkan dari nilai tertinggi, sedang dan rendah.

Penelitian ini menggunakan metode deskriptif kualitatif dimana hal tersebut menggambarkan atau melukiskan objek penelitian berdasarkan fakta yang sebenarnya terjadi. Penelitian bertujuan untuk menganalisa kesalahan siswa dalam menyelesaikan soal matematika pada materi aritmatika sosial. Instrumen tes sebelum digunakan sudah diuji validasi kemudian diujicobakan kembali kepada subjek yang sudah mempelajari materi aritmatika sosial.

Teknik analisis data dengan cara mempersentasekan kesalahan siswa dalam menyelesaikan masalah menggunakan rumus:

Keterangan:

$$
P=\frac{x}{N} \times 100 \%
$$

$\mathrm{P}=$ Persentase masing-masing jenis kesalahan

$x$ = Jumlah responden yang jawabannya salah

$N=$ Jumlah responden secara keseluruhan 


\section{HASIL DAN PEMBAHASAN}

Berdasarkan hasil tes soal cerita pokok bahasan aritmatika sosial terhadap siswa SMP Bina Putera Indonesia kelas VIII di Padalarang Bandung, didapatkan hasil seperti terlihat pada Tabel 1.

Tabel 1.

Data nilai kesalahan siswa berdasarkan KKM

\begin{tabular}{|c|c|c|c|c|c|}
\hline \multirow{2}{*}{ Butir soal } & \multirow{2}{*}{$\begin{array}{l}\text { Nilai SMI/ } \\
\text { Butir soal }\end{array}$} & \multirow{2}{*}{$\begin{array}{c}\text { Nilai KKM } \\
75 \%\end{array}$} & \multirow{2}{*}{$\begin{array}{c}\text { Siswa yang } \\
\text { mendapat nilai } \\
\geq \mathrm{KKM}\end{array}$} & \multicolumn{2}{|c|}{ Persentase } \\
\hline & & & & $\geq \mathrm{KKM}$ & $<\mathrm{KKM}$ \\
\hline 1 & 4 & 7.5 & 4 & $60 \%$ & $40 \%$ \\
\hline 2 & 4 & 7.5 & 2 & $30 \%$ & $70 \%$ \\
\hline 3 & 4 & 7.5 & 3 & $45 \%$ & $55 \%$ \\
\hline 4 & 4 & 7.5 & 1 & $15 \%$ & $85 \%$ \\
\hline
\end{tabular}

Data pada Tabel 1 menunjukkan bahwa kesalahan siswa berdasarkan KKM diperoleh hasil nilai siswa bervariasi. Pada butir soal no 1 bahwa tingkat kesalahan siswa dalam mengerjakan soal tersebut memiliki nilai $40 \%$, butir soal no 2 memiliki tingkat kesalahan siswa dalam mengerjakan soal sebesar $70 \%$, butir soal no 3 memiliki tingkat kesalahan siswa dalam mengerjakan soal sebesar $55 \%$ dan butir soal no 4 memiliki tingkat kesalahan siswa dalam mengerjakan soal sebesar $85 \%$. Maka dapat disimpulkan bahwa nilai kesalahan siswa dari Tabel 1 di atas lebih tinggi dibandingkan dengan jawaban benar siswa pada soal aritmatika sosial. Kesalahan siswa dalam menyelesaikan soal matematika dibagi menjadi empat kategori, diantaranya: (1) kesalahan konsep; (2) kesalahan prinsip; (3) kesalahan teknik; dan (4) kesalahan algoritma. Kurang lengkapnya langkah dan kurang mampunya siswa untuk memanipulasi langkah-langkah penyelesaikan soal.

\section{Analisis Kesalahan Jawaban Soal Nomor 1} dibawah ini.

Untuk mengetahui setiap kesalahan siswa dalam mengerjakan soal dapat dilihat pada tabel

Tabel 2.

Deskripsi kesalahan jawaban siswa soal nomor 1

\begin{tabular}{lc}
\hline \multicolumn{1}{c}{ Keterangan } & Kode Siswa \\
\hline Siswa tidak mencantumkan apa yang diketahui dari soal tersebut & \\
Siswa tidak menuliskan apa yang ditanyakan dari soal tersebut & $\mathrm{S} 1$ \\
Siswa tidak mencantumkan rumus soal yang telah ditentukan & \\
Siswa tidak mengubah soal cerita ke dalam bentuk model matematika & \\
Siswa tidak menyimpulkan hasil nilai dari apa yang dikerjakan & $\mathrm{S} 1$ \\
\hline
\end{tabular}

Berdasarkan hasil deskripsi kesalahan siswa dalam menjawab soal nomor 1 dapat diketahui bahwa siswa tidak menuliskan apa yang ditanyakan dari soal dan tidak menyimpulkan hasil jawaban. Untuk lebih jelas hasil jawaban siswa bisa dilihat pada Gambar 1 berikut. 


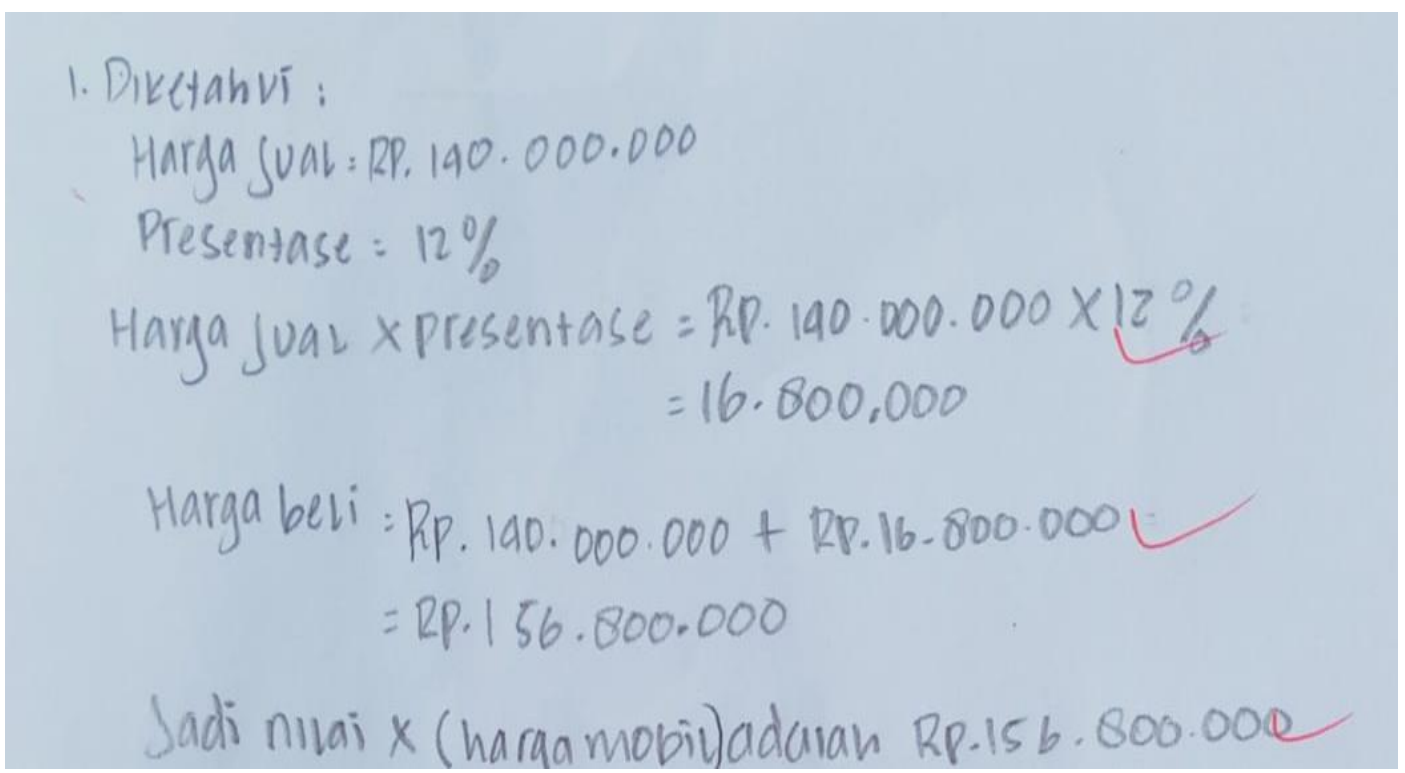

Gambar 1. Kesalahan siswa dalam menjawab soal nomor 1

Berdasarkan dari kesalahan jawaban siswa maka peneliti melakukan wawancara terhadap siswa. Berikut ini akan ditampilkan hasil wawancara dengan siswa tersebut.

Guru : Apa yang diketahui pada soal no 1?

Nova : Harga jual Rp. $140.000 .000,00$ dan persentase $12 \%$ bu

Guru : Apa yang ditanyakan pada soal no 1?

Nova : Harga awal mobil Pak Samsu bu

Guru : Apakah kamu mencantumkan jawaban hal tersebut ke dalam soal no 1?

Nova : Tidak bu.

Guru : Kenapa kamu tidak cantumkan?

Nova : Karena saya terfokuskan pada angka yang udah diketahuinya bu.

Berdasarkan hasil wawancara tersebut maka dapat dilihat bahwa siswa kurang teliti dalam mengerjakan soal yang diberikan.

\section{Analisis Kesalahan Soal Nomor 2}

Tabel 2.

Deskripsi kesalahan jawaban siswa soal nomor 2

\begin{tabular}{lc}
\hline \multicolumn{1}{c}{ Keterangan } & Kode siswa \\
\hline Siswa tidak mencantumkan apa yang diketahui dari soal tersebut & S1, S2, S3 \\
Siswa tidak menuliskan apa yang ditanyakan dari soal tersebut & S1, S2, S3 \\
Siswa tidak menantumkan rumus soal yang telah ditentukan & S1, S2, S3 \\
Siswa tidak mengubah soal cerita ke dalam bentuk model matematika & \\
Siswa tidak menyelesaikan soal yang diberikan & S1, S2, S3 \\
Siswa tidak menyimpulkan hasil nilai dari apa yang dikerjakan & \\
\hline
\end{tabular}

Berdasarkan hasil deskripsi kesalahan siswa dalam menjawab soal nomor 2 dapat diketahui bahwa siswa tidak menuliskan apa yang ditanyakan, apa yang diketahui, serta tidak menyelesaikan hasil jawaban yang diberikan dari soal. Maka berdasarkan deskripsi kesalahan siswa dalam menjawab dapat diketahui bahwa siswa tidak teliti dalam membaca soal, siswa tidak memaksimalkan waktu dengan baik. Berikut ini hasil jawaban siswa soal nomor 2 terlihat pada Gambar 2. 


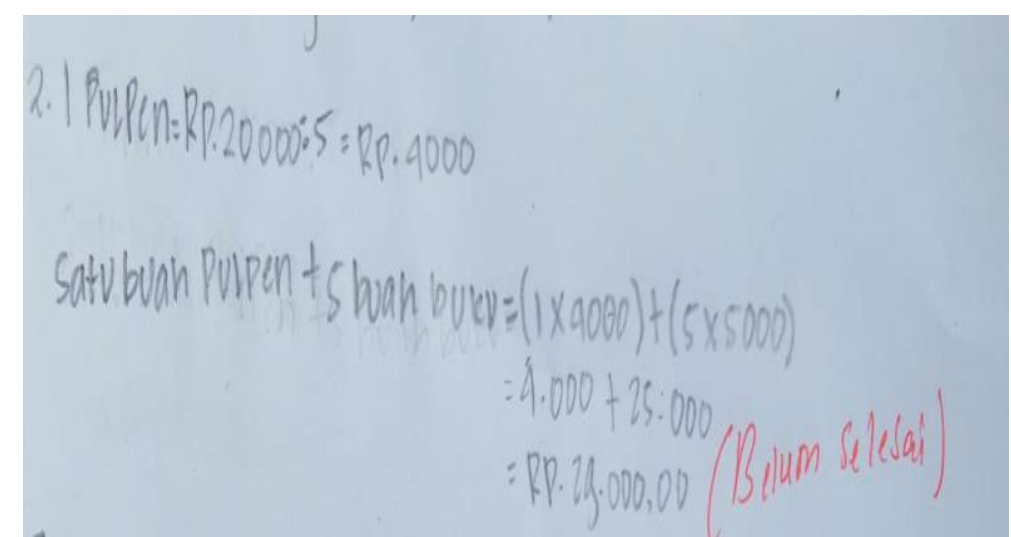

Gambar 2. Kesalahan siswa dalam menjawab soal nomor 2

Berdasarkan dari kesalahan jawaban siswa pada soal nomor 2 maka peneliti melakukan wawancara terhadap siswa. Hasil wawancara tersebut disajikan berikut.

Guru : Dari pertanyaan soal no 2 kenapa kamu tidak mengerjakannya dengan selesai?

Siswa: Karena saya mengerjakan soal no 2 terakhir bu, jadi soal yang mudah dulu saya kerjakan tersebut?

Siswa: Lupa bu

Guru : Apa yang diketahui pada soal no 2?

Siswa: Roni ingin membeli sebuah pulpen dan 5 buku tulis bu

Dari petikan wawancara di atas dapat terlihat bahwa siswa tidak menguasai materi dengan baik, selain itu siswa tergesa-gesa sehingga tidak menyelesaikan soal yang diberikan.

\section{Analisis Kesalahan Jawaban Siswa Nomor 3}

\section{Tabel 3.}

Deskripsi kesalahan jawaban siswa soal nomor 3

\begin{tabular}{lc}
\hline \multicolumn{1}{c}{ Keterangan } & Kode siswa \\
\hline Siswa tidak mencantumkan apa yang diketahui dari soal tersebut & $\mathrm{S} 4, \mathrm{~S} 5$ \\
Siswa tidak menuliskan apa yang ditanyakan dari soal tersebut & \\
Siswa tidak menantumkan rumus soal yang telah ditentukan & $\mathrm{S} 4, \mathrm{~S} 5$ \\
Siswa tidak mengubah soal cerita ke dalam bentuk model matematika & \\
Siswa tidak menyelesaikan soal yang diberikan & \\
Siswa tidak menyimpulkan hasil nilai dari apa yang dikerjakan & $\mathrm{S} 4, \mathrm{~S} 5$ \\
\hline
\end{tabular}

Berdasarkan hasil deskripsi kesalahan siswa dalam menjawab soal nomor 3 dapat diketahui bahwa siswa tidak mencantumkan apa yang diketahui dari soal, siswa tidak mencantumkan rumus matematika yang telah ditentukan dan siswa tidak menyimpulkan hasil jawaban yang dikerjakan. Maka dapat disimpulkan bahwa siswa tidak teliti dalam mengerjakan soal, siswa terburu-buru mengerjakan soal berikut ini hasil jawaban siswa soal nomor 3 dapat dilihat pada Gambar 3. 


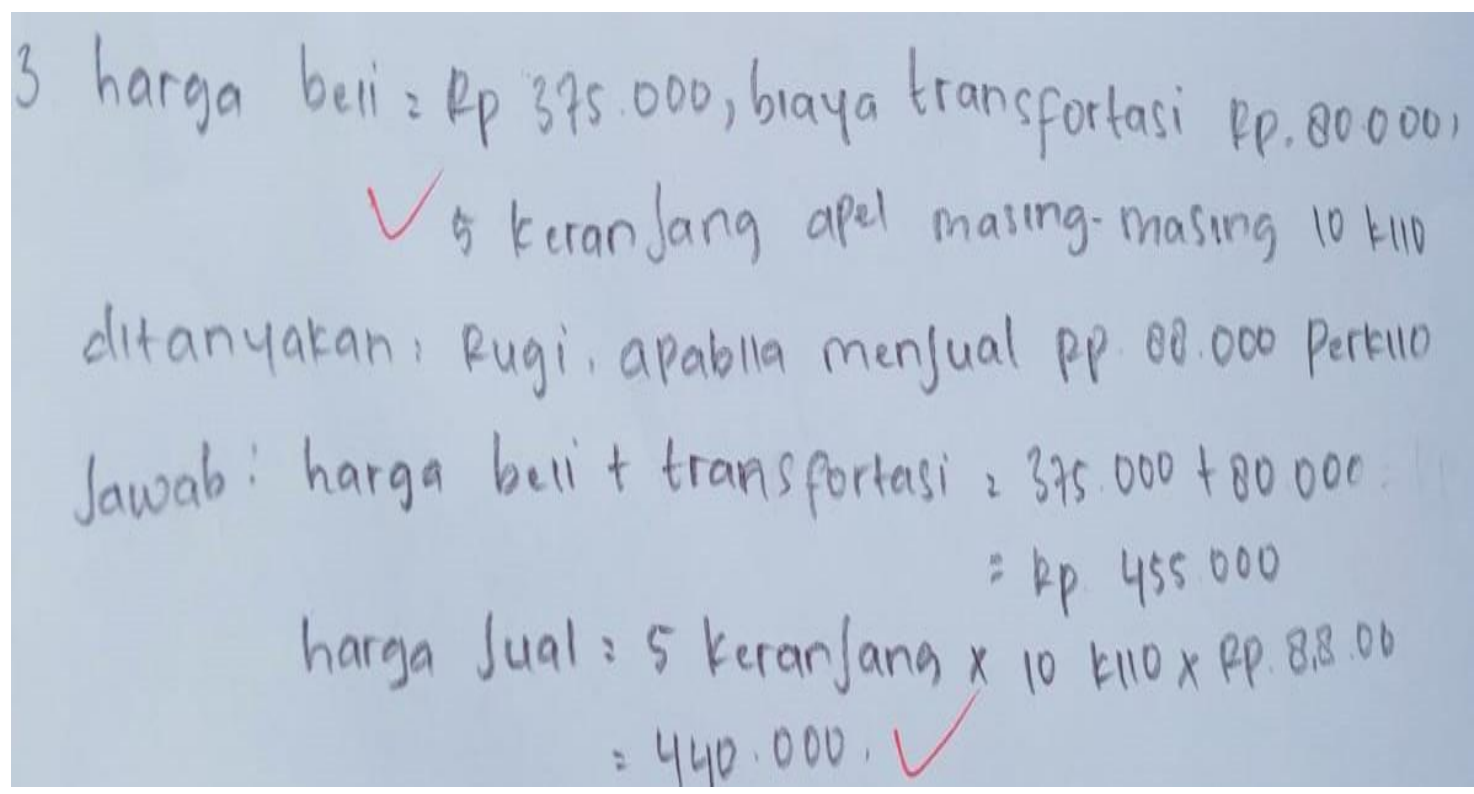

Gambar 3. Kesalahan siswa dalam menjawab soal nomor 3

Berdasarkan dari kesalahan jawaban siswa pada soal nomor 3 maka peneliti melakukan wawancara terhadap siswa. Hasil wawancara tersebut disajikan berikut.

Guru : Kenapa pada soal nomor 3 kamu tidak mengerjakannya dengan teliti?

Siswa: lya bu

Guru : Jawabanmu sudah hampir benar, tapi kenapa kamu tidak selesai mengerjakannya?

Siswa: waktunya gak cukup bu

Dari petikan tersebut nampak bahwa siswa tidak memaksimalkan waktu yang diberikan dan kurang teliti dalam menjawab soal.

\section{Analisis Kesalahan Jawaban Siswa Nomor 4}

Tabel 4.

Deskripsi kesalahan jawaban siswa soal nomor 4

\begin{tabular}{lc}
\hline \multicolumn{1}{c}{ Keterangan } & Nama siswa \\
\hline Siswa tidak mencantumkan apa yang diketahui dari soal tersebut & S1, S3, S5, S4 \\
Siswa tidak menuliskan apa yang ditanyakan dari soal tersebut & $\mathrm{S} 1$, S3, S5, S4 \\
Siswa tidak mencantumkan rumus soal yang telah ditentukan & $\mathrm{S} 3$, S5, S4 \\
Siswa tidak mengubah soal cerita ke dalam bentuk model matematika & \\
Siswa tidak menyelesaikan soal yang diberikan & \\
Siswa tidak menyimpulkan hasil nilai dari apa yang dikerjakan & S1, S3, S5, S4 \\
\hline
\end{tabular}

Berdasarkan hasil deskripsi kesalahan siswa dalam menjawab soal nomor 4 dapat diketahui bahwa siswa tidak menuliskan apa yang diketahui dan ditanyakan dari soal yang diberikan, siswa tidak mencantumkan rumus yang telah ditentukan dan siswa tidak menyimpulkan hasil jawaban yang dikerjakan. Maka berdasarkan deskripsi kesalahan siswa dalam menjawab dapat diketahui bahwa siswa tidak teliti dalam membaca soal, siswa tidak memaksimalkan waktu dengan baik, siswa tergesagesa dalam menjawab. Berikut ini hasil jawaban siswa soal nomor 4 dapat dilihat pada Gambar 4. 


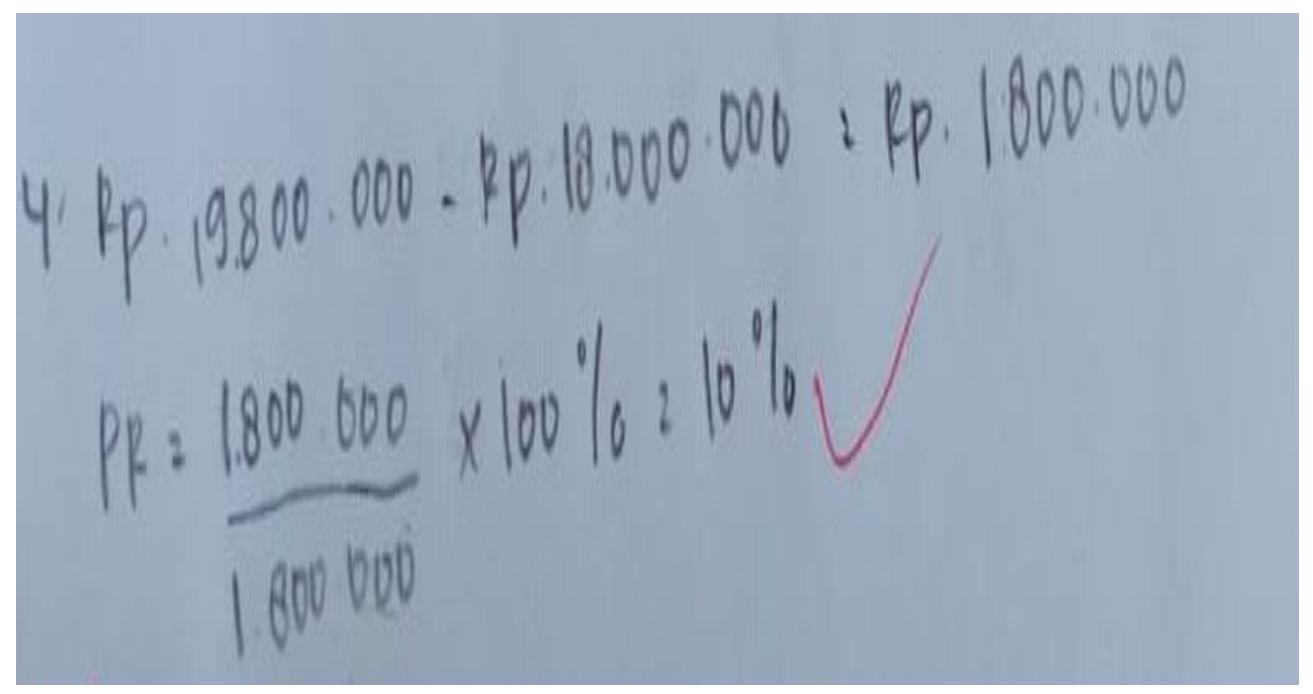

\section{Gambar 4. Kesalahan siswa dalam menjawab soal no 4}

Berdasarkan dari kesalahan jawaban siswa pada soal nomor 4 maka peneliti melakukan wawancara terhadap siswa. Hasil wawancara tersebut disajikan berikut.
Guru : Kenapa pada soal nomor 4 kamu tidak mengerjakannya dengan teliti?
Siswa : Gak bu.
Gur : Coba ingat kembali, apakah kamu menuliskan rumus di dalam soal?
Siswa : Tidak bu, soalnya saya buru-buru mengerjakannya.
Guru : Apakah kamu belajar?
Siswa : Tidak bu, karena saya menunggu ayah saya beliau sedang sakit
Guru : Dirumah atau dirumah sakit?
Siswa : Dirumah bu.

Dari petikan wawancara tersebut nampak bahwa siswa kurang fokus dan teliti dalam menjawab soal yang diberikan. Hasil penelitian ini sejalan dengan penelitian Sari et.al (2018) bahwa kesalahan siswa dalam mengerjakan soal cerita diakibatkan karena kurang ketelitian siswa, kesalahan siswa dalam mengubah soal cerita ke dalam model matematika, tergesa-gesanya siswa dalam menjawab soal dan kurangnya pemahaman siswa dalam memahami konsep matematika yang diberikan.

\section{KESIMPULAN}

Berdasarkan dari hasil pembahasan di atas maka dapat diambil kesimpulan kesalahankesalahan yang dilakukan siswa dalam menyelesaikan soal cerita pada materi aritmatika sosial adalah sebagai berikut: (1) kesalahan tipe 1, yaitu siswa dalam mengerjakan soal tidak menulis apa yang diketahui dan ditanyakan. Hal ini disebabkan siswa tidak teliti dalam membaca soal, siswa tidak memahami apa yang dimaksud dalam pertanyaan soal, siswa tergesa-gesa dalam mengerjakan soal, dan siswa tidak membaca petunjuk soal; (2) kesalahan tipe 2, yaitu siswa tidak mengubah soal cerita kedalam bentuk model matematika. Hal ini disebabkan siswa tidak memahami apa yang dimaksud dalam soal tersebut, siswa tidak teliti dalam mengerjakan soal, serta siswa tidak membaca soal dengan baik; (3) kesalahan tipe 3, yaitu kesalahan siswa dalam melakukan operasi bilangan bulat dan bilangan desimal. Hal ini disebabkan siswa tidak dapat menghitung nilai persen kedalam bentuk desimal, siswa tidak teliti dalam membaca soal, siswa kesulitan dalam operasi pengurangan dan penjumlahan.

\section{REKOMENDASI}

Berdasarkan hasil penelitian yang telah dipaparkan, peneliti menyatakan bahwa menganalisis hasil kesalahan siswa dalam menjawab soal cerita perlu dilakukan. Peneliti memberikan rekomendasi sebagai berikut: penelitian ini dilakukan untuk mengetahui kesalahan siswa dalam menyelesaikan soal 
cerita, untuk itu kepada pihak sekolah khususnya kepada guru matematika agar melakukan tindakan lanjutan guna mendukung keberhasilan dan pemahaman siswa dalam berbagai model soal matematika khususnya soal cerita. Dari hasil peneitian yang dilakukan bahwa kesalahan siswa adalah mengubah soal cerita ke dalam bentuk model matematika. Selain itu peneliti hanya menganalisis soal pada materi aritmatika social. Oleh karena itu peneliti menyarankan kepada pihak lain untuk bisa melakukan analisis kesalahan siswa kepada subjek yang lebih luas dengan menggunakan materi matematika lain.

\section{UCAPAN TERIMA KASIH}

Peneliti mengucapkan terima kasih banyak terhadap semua orang yang telah berkontribusi dalam penelitian ini, yaitu kepada orang tua yang telah mendukung setiap langkah-langkah yang peneliti lakukan, kepada kepala sekolah SMP Bina Putera Indonesia yang telah mengizinkan saya untuk melakukan penelitian di sekolah tersebut, serta kepada siswa yang telah membantu peneliti.

\section{DAFTAR PUSTAKA}

Aminah, S., Wijaya, T. T., \& Yuspriyati, D. (2018). Analisis kemampuan komunikasi matematis siswa kelas viii pada materi himpunan. Jurnal Cendekia: Jurnal Pendidikan Matematika, 2(1), 15-22.

Andayani, F., \& Lathifah, N, A. (2019). Analisis kemampuan pemecahan masalah siswa smp dalam menyelesaikan soal pada materi aritmatika sosial. Jurnal Pendidikan Matematika, 3(1), 1-10.

Astutik, Y., \& Kurniawan, L. (2015). Analisis kesalahan siswa dalam menyelesaikan soal cerita aritmatika sosial. Jurnal Pendidikan Matematika STKIP PGRI Sidoarjo, 3(1), 95-100.

Fatimah, A. T., \& Zakiah, N. E. (2018). Kelancaran prosedural matematis dalam pemecahan masalah konteks pemasaran. Mathline Jurnal Matematika dan Pendidikan Matematika, 3(2), 141-150.

Halim, F., \& Rasidah, N. (2019). Analisis kesalahan siswa dalam menyelesaikan (analysis of student errors in resolving the problem of. Gauss: Jurnal Pendidikan Matematika, 02(01), 35-44.

Henidarwati, Hasbi, M., \& Madeli, T. (2016). Penerapan model pembelajaran kooperatif tipe numbered heads together pada materi aritmatika sosial untuk meningkatkan hasil belajar siswa kelas vii smp negeri 10 palu. Aksioma Jurnal Pendidikan Matematika.

Inayah, F. F. (2018). Penerapan teori situasi didaktik pada materi aritmatika sosial. Jurnal Penelitian Didaktik Matematika, (2), 35-47.

Isna, N. N., \& Kurniasari, I. (2018). Identifikasi tingkat berpikir kreatif siswa dalam menyelesaikan open ended problem materi aritmatika sosial smp ditinjau dari kemampuan matematika. Jurnal IImiah Pendidikan Matematika, 7(3), 607-613.

Lutfia, L., \& Zanthy, L. S. (2018). Analisis kesalahan menurut tahapan kastolan dan pemberian scaffolding dalam menyelesaikan soal sistem persamaan linear dua variabel. Journal on Education, 01(03), 396-404.

Mulianty, R. H., Hanafiah, N. A., \& Sugandi, I. A. (2018). Hubungan antara kemampuan pemahaman matematik dengan kemandiian belajar siswa smp yang menggunakan pendekatan kontekstual. Jurnal Pembelajaran Matematika Inovatif. 
Mulyani, N., \& Hanifah. (2018). Analisis kesulitan siswa dalam menyelesaikan soal pemecahan masalah matematis siswa pada materi aritmatika sosial. Prosiding Sesiomadika 22, 469-477.

Nurussafa'at, F. A., Sujadi, I., \& Riyadi, R. (2016). Analisis kesalahan siswa dalam menyelesaikan soal cerita pada materi volume prisma dengan fong's shcematic model for error analysis ditinjau dari gaya kognitif siswa. Jurnal Pembelajaran Matematika, 4(2), 174-187.

Nuryana, D., \& Rosyana, T. (2019). Analisis kemampuan pemecahan masalah matematis siswa smk pada materi program linear. Jurnal Cendekia: Jurnal Pendidikan Matematika, 3(1), 11-20.

Paramitha, N. (2017). Analisis proses berpikir kreatif dalam memecahkan masalah matematika materi aritmatika sosial siswa smp berkemampuan tinggi. Jurnal Mitra Pendidikan (JMP Online), 1(10), 983-994.

Permatasari, S. W. E. (2014). Implementasi model pembelajaran contextual teaching and learning (ctl) pada standar kompetensi dasar memasang instalasi penerangan listrik di smkn 7 surabaya. Jurnal Pendidikan Teknik Elektro, 3(2), 47-53.

Rismawati, M., \& Asnayani, M. (2019). Analisis kesalahan konsep siswa dalam menyelesaikan soal ulangan matematika dengan metode newman. J-Pimat, 1(2), 69-78.

Rofi'ah, N., Ansori, H., \& Mawaddah, S. (2019). Analisis kesalahan siswa dalam menyelesaikan soal cerita matematika berdasarkan langkah penyelesaian polya. EDU-MAT: Jurnal Pendidikan Matematika, 7, 120-129, https://doi.org/10.20527/edumat.v7i2.7379.

Sari, A. M., Susanti, N., \& Rahayu, C. (2018). Analisis kesalahan siswa dalam menyelesaikan soal cerita materi aritmatika sosial kelas VII. Jurnal Penelitian Pendidikan dan Pengajaran Matematika, 4(2), 61-68.

Setiani, D., Suryana, Y., \& Pranata, O. H. (2018). Pengaruh pendekatan matematika realistik terhadap kemampuan menyelesaikan soal cerita tentang aritmatika sosial uang. Pedadidaktika: Jurnal IImiah Pendidikan Guru Sekolah Dasar, 5(3), 174-180.

Simarmata, A. M., Wibowo, M. R. H., Hutajulu, M., \& Hendriana, H. (2018). Motivasi belajar siswa smp dengan menggunakan. Jurnal Prisma, VII(2), 135-144.

Susilowati, L., \& Ratu, N. (2018). Analisis kesalahan siswa berdasarkan tahapan newman. Mosharafa, 7, 13-24.

Wahyudin. (2016). Analisis kemampuan menyelesaikan soal cerita matematika ditinjau dari kemampuan verbal. Beta: Jurnal Tadris Matematika, 9(2), 148-160.

Wahyuni, D. S. (2018). Penerapan pendekatan pembelajaran contextual teaching and learning (ctl) untuk meningkatkan hasil belajar siswa kelas viii c pada materi luas dan keliling lingkaran di mts birobuli. Scolae: Journal of Pedagogy, 1(1), 77-83.

Zakiah, N. E., Sunaryo, Y., \& Amam, A. (2019). Implementasi pendekatan kontekstual pada model pembelajaran berbasis masalah berdasarkan langkah-langkah polya. Teorema: Teori dan Riset Matematika, 4(2), 111-120. 
•116 Teorema: Teori dan Riset Matematika, 5(1), 105-116, Maret 2020

Zanthy, L. S. (2016). Pengaruh motivasi belajar ditinjau dari latar belakang pilihan jurusan terhadap kemampuan berpikir kritis mahasiswa di stkip siliwangi bandung. Teorema: Teori dan Riset Matematika, 1(1), 47-54. 